\title{
Genotyping of Chlamydia trachomatis serovars derived from heterosexual partners and a detailed genomic analysis of serovar $\mathrm{F}$
}

J Lan, C J L M Meijer, A R van den Hoek, J M Ossewaarde, J M M Walboomers, A J C van den Brule

\begin{abstract}
Objective-To investigate $C$ trachomatis serovars in contact-traced heterosexual partners.

Methods-Urogenital Chlamydia trachomatis isolates $(n=112)$ derived from 35 heterosexual patients (index patients) and their 37 chlamydia positive partners (contact patients) were differentiated into serovars by genotyping with restriction fragment length polymorphism (RFLP) analysis of the PCR amplified omp1 gene. In order to investigate whether different strains within the frequently prevalent serovar $F$ were transmitted, two pairs of serovar $F(n=4)$ were further analysed by genomic DNA fingerprinting with arbitrary primer PCRs (AP-PCRs).

Results-Identical C trachomatis serovars were found in 31 of the 35 pairs, serovars $E, F, D$, and $G$ being most prevalent. In the remaning four pairs different serovars (either $D, E, F$ or $G$ ) were found between the index and the contact patients. By AP-PCR analysis the strains of serovar $F$ were found to be identical between the index and the contact patients, but were different between the two pairs in all AP-PCRs used.

Conclusion-A majority of heterosexual partners, once traced positive for C trachomatis infections, are infected with identical serovars. Identical strains of serovar $F$ found in partners as found by DNA fingerprinting confirms the sexual transmission of $\boldsymbol{C}$ trachomatis.
\end{abstract}

(Genitourin Med 1995;71:299-303)

Keywords: Chlamydia trachomatis; contacts; PCR

\section{Introduction}

Chlamydia trachomatis is very prevalent in urogenitial infections and is transmitted through sexual contact. Fifteen major serovars have currently been classified: A, B, Ba, C, D, E, F, G, H, I, J, K, L1, L2, and L3.' Serovars D to $\mathrm{K}$ are responsible for urogential infections, of which serovars $E, F$ and $D$ account for up to $60-70 \%$ of these infections. ${ }^{2-5}$ To date epidemiological studies of $C$ trachomatis infections in sexual contacts have been few, ${ }^{\text {sa }}$ which hampers the study of $C$ trachomatis transmission, of the route of spread in a population, of chlamydial virulence factors and of insight into the associated risk factors of $C$ trachomatis infections.
Typing of $C$ trachomatis serovars has so far been limited to the identification with monoclonal antibodies (MAbs) (serotyping) of specific immunoepitopes carried by the major outer membrane protein (Omp1) ${ }^{6-7}$ Analysis of the corresponding $o m p 1$ gene has also been used for the typing of $C$ trachomatis serovars. ${ }^{4-58-15}$ This was successfully achieved by using restriction fragment length polymorphism (RFLP) analysis, ${ }^{4-5-12}$ differential dotblot hybridisation, ${ }^{13}$ or direct DNA sequencing of this $o m p 1$ gene. ${ }^{14} 15$ The omplRFLP genotyping for differentiation of $C$ trachomatis serovars was validated and found as a very reliable and easily-performed method as compared with the ompl serotyping. ${ }^{11} 21$ Epidemiological data have been obtained by using either serotyping or genotyping methods, whereby a number of $C$ trachomatis substrains (serovariants or genovariants) have been identified. ${ }^{16-21}$

Amongst the most prevalent serovars D, E, and $F$, serovar $D$ was found to possess extensive omp 1 genetic diversity, whereas serovars $\mathrm{E}$ and $\mathrm{F}$ had relatively stable ompl genes as shown by either RFLP Rr nucleotide $^{4}$ sequence analysis of this gene. ${ }^{19-2022}$ So far, these techniques have only been used for analysing the ompl gene. Techniques with greater discriminatory power capable of differentiating $C$ trachomatis strains within a certain serovar are necessary for a higher resolution in transmission studies, particularly for the highly prevalent serovars $D, E$ and $F$. With the advent of DNA fingerprinting technology, it is now possible to analyse genetic differences of closly related bacterial strains by studying genomic DNA. ${ }^{2324}$ Recently, a highly sensitive DNA fingerprinting method by using arbitrary primer mediated amplification of the genomic DNA by polymerase chain reaction (AP-PCR) was introduced. ${ }^{25}$ It was also shown that by using assay $C$ trachomatis serovars could be differentiated into several groups according to DNA banding patterns generated, but the grouping was different from the current serovar grouping. ${ }^{26}$ So far, this technique has not been used for epidemiological studies of chlamydial infections or for transmission studies of $C$ trachomatis strains derived from the sexual partners.

In this study, $C$ trachomatis strains isolated from heterosexual patients and their contacts, attending a sexually transmitted disease (STD) outpatient clinic, were analysed by using omp1-RFLP genotyping. ${ }^{12-13}$ To determine whether identical strains are transmitted between sexual partners, several serovar $F$ iso- 
Table 1 List of primers used for AP-PCRs with chlamydial genomic DNA*

\begin{tabular}{lll}
\hline Code & Nucleotide sequence & Reference \\
\hline ERIC1R & 5'-ATGTAAGCTCCTGGGGATTCAC-3' & 23 \\
ERIC 2 & 5'-AAGTAAGTGACTGGGGTGAGCG-3' & 23 \\
REP1RI & 5'-XXXXCGXCGXCATCXGGC-3' & 23 \\
REP2I & 5'-XCGXCTTATCXGGCCTAC-3' & 23 \\
\hline
\end{tabular}

« $\mathrm{X}$ represents nucleotide $\mathrm{A}, \mathrm{T}, \mathrm{G}$ or $\mathrm{C}$.

lates were further analysed by chlamydial DNA fingerprinting using AP-PCRs.

\begin{abstract}
Material and Methods
$C$ trachomatis isolates

$C$ trachomatis isolates $(\mathrm{n}=112)$ obtained from 35 heterosexual patients (index patients) and their $C$ trachomatis-infected partners (contact patients, $n=37$ ), were included in this study. These patients ${ }^{27}$ attended a STD clinic of Municipal Health Service, Amsterdam, between September 1986 and December 1988. All women were sampled from cervix, urethra and anus, All men were sampled from the urethra. HeLa 229 cell culture was used for $C$ trachomatis detection in shell vials. ${ }^{28}$ The index patients included 20 men and 15 women, and the 37 contact patients included 22 women and 15 men. The mean ages of women and men were 28 and 31 years, respectively. Homosexuals were not included in this study.
\end{abstract}

\section{omp1-RFLP genotyping}

The $C$ trachomatis omp 1 gene was amplified by PCR as previously described, ${ }^{912}$ with primers SERO1A (5'-ATGAAAAAACTCTTGAAATCGG-3') and SERO2A (5'-TTTCTAGA(T/C)TTCAT(T/C)TTGTT-3'). Briefly, $1 \mu \mathrm{l}$ of $C$ trachomatis isolate was heat denatured and pipetted into $49 \mu \mathrm{l}$ of PCR reaction mixture, containing $50 \mathrm{mM} \mathrm{KCl}$, $1.5 \mathrm{mM} \mathrm{MgCl}_{2}, 10 \mathrm{mM}$ Tris- $\mathrm{HCl}$ (pH8.3), $200 \mu \mathrm{M}$ of each deoxynucleotide (dATP, dT TP, dGTP and dCTP), $50 \mathrm{pmol}$ of each primer, and $1 \mathrm{U}$ Taq polymerase (Amplitaq, Perkin Elmer, Branchburg, New Jersey). The PCR amplification was carried out in a thermocycler (Biomed, Theres, Germany) for 49 cycles of amplication, consisting of denaturation at $95^{\circ} \mathrm{C}$ for $1 \mathrm{~min}$, annealing at $45^{\circ} \mathrm{C}$ for 2 min, and chain elongation at $72^{\circ} \mathrm{C}$ for $3 \mathrm{~min}$. For RFLP genotyping the $o m p 1$ PCR products were principally digested with AluI and analysed on a $7 \%$ polyacrylamide gel (acrylamide/bis-acrylamide: $29 / 1$ ) to differentiate serovars $\mathrm{Ba}, \mathrm{D}, \mathrm{E}, \mathrm{F}, \mathrm{G}, \mathrm{K}$ and $\mathrm{C}$-complex serovars (C, J, H, I, L3). The C-complex serovars were further differentiated by digestion of the ompl PCR products with HinfI and the combination of EcoRI and DdeI. Serovar $\mathrm{D}$ was further differentiated into $\mathrm{D}$, $\mathrm{Da}$ or $\mathrm{D}^{-}$by CfoI. ${ }^{12}$

\section{Arbitrary primer PCR}

$C$ trachomatis genomic DNA was obtained after purification of the elementary bodies (EBs) with a slightly modified protocol as previously described. ${ }^{28} C$ trachomatis isolates cultured in large quantities in HeLa229 cells in six-well microtiter plates (Becton Dekinson, UK) were harvested in phosphate buffered saline (PBS). The cell suspension was sonicated 3 times for $10 \mathrm{~s}$ to break down the HeLa229 cells and subsequently centrifuged at $500 \times g$ for $15 \mathrm{~min}$ to remove the cell debris. The supernatant was centrifuged for $30 \mathrm{~min}$ at $25000 \times g$ at $20^{\circ} \mathrm{C}$. The pellet was resuspended in PBS and purified by centrifugation for $45 \mathrm{~min}$ at $25000 \times \mathrm{g}$ at $20^{\circ} \mathrm{C}$ through a layer of $35 \%$ sodium diatrizoate (Sigma). The pellet containing the EBs was digested with DNase-I to eradicate HeLa229 DNA. After heat inactivation $(10 \mathrm{~min}$ at $65^{\circ} \mathrm{C}$ ) the $\mathrm{EBs}$ were lysed with proteinase $\mathrm{K}$ $(50 \mu \mathrm{g} / \mathrm{ml})$ and Tween $20(0 \cdot 45 \%) .{ }^{12}$ The suspension was extracted twice with phenol/chloroform (24:25), and the chlamydial DNA was precipated with ethanol and resuspended in Tris- $\mathrm{HCl}(\mathrm{pH} 8 \cdot 3)$. The purity of chlamydial DNA was confirmed by failure to detect human $\beta$-globin with PCR. ${ }^{29}$ Human liver DNA was used as a positive control for the $\beta$ globin PCR. Thereafter, a portion of $50 \mathrm{ng}$ of purified chlamydial DNA was amplified in different AP-PCRs with different primers (Table 1). The AP-PCR was performed for 40 cycles of amplification, of which each cycle consisted of denaturation at $95^{\circ} \mathrm{C}$ for $1 \mathrm{~min}$, annealing at $25^{\circ} \mathrm{C}$ for $1 \mathrm{~min}$ and chain elongation at $72^{\circ} \mathrm{C}$ for $3 \mathrm{~min}$. The PCR reaction mixture was identical to that used for the ompl PCR, except that $2.5 \mathrm{mM} \mathrm{MgCl} 2$ was used. HeLa229 DNA was used in order to ensure that HeLa229 DNA, if present in such a minimal amount that was not detected by $\beta$ globin PCR, was not interfering with the chlamydial DNA amplification in these low stringency AP-PCRs. The amplified fragments of DNA were analysed with $2 \%$ agarose gel electrophoresis.

\section{Results}

Thirty-five pairs of isolates from patients and contacts with chlamydial urogenital infections were investigated for their $C$ trachomatis serovars. By omp1-RFLP genotyping identical serovars were found in 31 of the 35 pairs (Table 2 and pairs $1-3$ in table 3 ). Among these 31 pairs, it was possible to trace a single partner who was chlamydia positive in 28 index patients. Of these 28 pairs, the cervices of the female partners was positive in 27 , the urethra and anus being variably positive, whereas in one $C$ trachomatis infection was

Table 2 C trachomatis serovar distributions in 28 contact-traced heterosexuul partnerships with identical serovars regardless of sampling sites

\begin{tabular}{lccc}
\hline & \multicolumn{2}{l}{ No of serovars (in pairs) } \\
\cline { 2 - 4 } Serovar & Men as index & Women as index & Total \\
\hline D & 2 & 1 & 3 \\
E & 6 & 5 & 11 \\
F & 7 & 2 & 9 \\
H & & 2 & 2 \\
J & 1 & 1 & 1 \\
Total & 17 & 11 & 1 \\
\hline
\end{tabular}


Table 3 C trachomatis serovar distributions in 7 heterosexual partnerships having i) the same serovar infections in one of the two partners (pair 1), ii) infections with identical serovars to only one of the two serovars (pairs 2-3), or iii) infections with different serovars (pairs 4-7)

\begin{tabular}{|c|c|c|c|c|c|c|c|c|c|}
\hline \multirow[b]{2}{*}{ Pair } & \multicolumn{3}{|c|}{ Index patient } & \multicolumn{3}{|c|}{ Contact 1} & \multicolumn{3}{|c|}{ Contact 2} \\
\hline & sex & site & serovar & sex & site & serovar & sex & site & serovar \\
\hline $\begin{array}{l}\text { i): } \\
1 \\
\text { iii). }\end{array}$ & f & $\mathrm{Cx} / \mathrm{Ure}$ & $\mathrm{E}$ & $\mathbf{m}$ & Ure & $\mathbf{E}$ & f & $\mathrm{Cx} /$ Ure & D \\
\hline 2 & $\mathbf{m}$ & Ure & $\mathbf{H}$ & f & $\begin{array}{l}\mathrm{Cx} \\
\text { Ure }\end{array}$ & $\underset{D}{H}$ & & & \\
\hline 3 & f & $\begin{array}{l}\text { Cx } \\
\text { Ure }\end{array}$ & $\begin{array}{l}\mathbf{F} \\
\mathrm{E}\end{array}$ & $\mathbf{m}$ & Ure & $\mathrm{F}$ & & & \\
\hline 4 & $\mathrm{~m}$ & Ure & D & f & $\mathrm{Cx} / \mathrm{Ure} / \mathrm{An}$ & E & & & \\
\hline $\begin{array}{l}5 \\
6 \\
7\end{array}$ & $\begin{array}{l}\mathrm{f} \\
\mathrm{m} \\
\mathrm{m}\end{array}$ & $\begin{array}{l}\text { An } \\
\text { Ure } \\
\text { Ure }\end{array}$ & $\begin{array}{l}E \\
F \\
F\end{array}$ & $\begin{array}{l}\mathrm{m} \\
\mathrm{f} \\
\mathrm{f}\end{array}$ & $\begin{array}{l}\text { Ure } \\
\mathrm{Cx} \\
\mathrm{Cx} / \mathrm{Ure}\end{array}$ & $\begin{array}{l}\text { F } \\
\text { D } \\
\text { G }\end{array}$ & $\mathrm{f}$ & $\mathrm{Cx} /$ Ure/An & G \\
\hline
\end{tabular}

$\mathrm{f}=$ female, $\mathrm{m}=$ male, $\mathrm{Cx}=$ cervix, Ure $=$ urethra, $\mathrm{An}=$ anus.

only detected in the urethra and anus. Of the remaining 3 of the 31 pairs, one pair had two contact partners traced who were chlamydia positive but only one of the contact partners was infected with an identical serovar as the index patients (Table 3, case 1); in the other two pairs the women had two different serovar infections in the cervix and urethra, while the male partners were infected with the serovars identical to those found in the cervix (Table 3, pairs 2 and 3). These 3 cases (Table 3, pairs 1-3) were therefore considered as pairs infected with the same serovars. Of these 31 pairs (Table 2 and pairs 1-3 in table 3 ), serovar $\mathrm{D}$ was found in 3 pairs, $\mathrm{E}$ in $12, \mathrm{~F}$ in $10, \mathrm{G}$ in $2, \mathrm{H}$ in $2, \mathrm{~J}$ in 1 , and $\mathrm{K}$ in 1 .No serovar I or serovariants $\mathrm{Da}$ and $\mathrm{D}^{-}$were found. When the men in the index group were analysed, the prevalence of serovar distribution was in a decreasing order of serovars $F$, $E, D$, and $H / J / K$. When the females in the index group were analysed, the prevalence of serovar distribution was in a decreasing order of serovars $\mathrm{E}, \mathrm{F}, \mathrm{G}$, and $\mathrm{D} / \mathrm{H}$. In the remaining 4 of the 35 pairs, different serovars were found between the index patients and their contact partners. Either serovar D, E, F or G was involved in these 4 pairs. In these 4 pairs, 3 had single contact partners (Table 3, pairs 4-6) and 1 had 2 contact partners traced who were $C$ trachomatis positive (Table 3, pair 7).

$D N A$ banding profiles from a representative $A P-P C R$ analysis with primer ERIC2 in two pairs of $C$ trachomatis serovar $F$ strains (pair 1: lanes 2 and 3 , pair 2: lanes 4 and 5) using purified EB DNA The strains derived from the partners were identical lanes 2 and 3 , lanes 4 and 5), while the strains from the different pairs (pairs 1 and 2) were different. Lane 1 represents a molecular weight marker with pBR322 DNA digested with HinfI. Lane 6 is an $A P-P C R$ control using Hela229, and lane 7 is a negative control. $b p=$ base pair.
Serovar $F$ isolates derived from two pairs were analysed by DNA fingerprinting with 4 different AP-PCRs. For this purpose, EBs were isolated and the purified DNA was shown to be free of HeLa229 DNA contamination by a negative human $\beta$-globin PCR. ${ }^{30}$ An additional omp1-RFLP genotyping of these purified chlamydial DNAs confirmed their initial genotyping results as serovar $\mathrm{F}$. Genomic DNA fingerprinting by AP-PCRs showed that each of the primers (ERIC1, ERIC2, REP1, or REP2) gave rise to specific amplified DNA banding profiles in all isolates tested, which could be clearly distinguished from the profiles of HeLa229 control. The DNA banding profiles with either ERIC1 or ERIC2 primers in the PCR were more clearly visible and discriminative after gel electrophoresis than those generated by either REP1 or REP2 primers. The F strains belonging to the same pairs were identical in all APPCRs tested. In contrast, the F strains of the two confirmed but non-related pairs, showed two different DNA banding profiles in all APPCRs analysed. The figure shows a representative AP-PCR analysis of the serovar F isolates from these two pairs using primer ERIC2.

\section{Discussion}

This study showed that the majority of the heterosexual pairs ( 31 of the 35 pairs) with chlamydial urogenital infections were infected with identical serovars. Serovars E, F, and D were the most prevalent types found in these 31 pairs (Table 2 and pairs $1-3$ in table 3 ). The frequency of the serovar distributions was similar to those found in STD populations in other European countries. ${ }^{235}$ The results found in this study are in agreement with those obtained by Viscidi et al, ${ }^{5 a}$ who found identical serovars (identified by nucleotide sequencing of a small fragment of the ompl gene) in a smaller group of 8 pairs. In addition, a slight difference in serovar $F$ prevalence was observed between male index patients (7 of the 17 pairs in table 2) and female index patients ( 2 of the 11 pairs in table 2). In another report, serovar $F$ was found to be associated with fewer clinical symptoms in women with cervicitis and pelvic 
inflammatory disease. ${ }^{30}$ In this study, in general all the male index patients were symptomatic whereas not all female index patients were found to have specific urogenital symptoms. Although the number of pairs in this study was small, these data may reflect the fact that the virulence of serovar $F$ is different in men and women.

It is worth noting that different serovar infections were found in different anatomical sites in two female patients of two pairs (Table 3, pairs 2-3). One was a contact patient infected with serovar $\mathrm{H}$ in the cervix and $\mathrm{D}$ in the urethra, and the other one was an index patient infected with serovar $\mathrm{H}$ in the cervix and D in the urethra, and the other one was an index patient infected with serovar $F$ in the cervix and $E$ in the urethra. Interestingly, both of their male partners were infected with a single serovar identical to the one found in the female cervix. In addition, in those 28 pairs with identical serovar infections (Table 2), a large majority of the female partners (27 pairs) had $C$ trachomatis identified in the cervix, no matter whether or not it was identified in urethra or anus. These data emphasise that $C$ trachomatis transmission might be restricted to the site of actual contact, that is, the cervix of women and the urethra of men.

In this study, chlamydial infections with different serovars between the index patients and their contacts were observed in five pairs (Table 3, pair 1 (the second contact) and pairs 4 to 7 ). One explanation may be that in these pairs double serovar infections existed, but were missed possibly because of preferential growth of one serovar in the cell culture. Unfortunately, the original specimens were no longer available for PCR testing. It would be extremely interesting to determine whether double serovar infections exist in such patients because certain serovars might be more virulent than others resulting in preferential transmission, or one of the serovars might be more susceptible to the host immune response and could be eradicated after entering a new host. Alternatively, one of the members of the pair may have already been infected with another $C$ trachomatis serovar which prevented infection by the newly introduced serovar.

Serovar F has been found to be one of the most prevalent types in different epidemiological studies. ${ }^{2-5}$ Since the genetic variation in its $o m p 1$ gene was found to be very low, ${ }^{4022}$ the analysis of the ompl either by RFLP or by nucleotide sequencies is not suitable for discriminating between different isolates. With AP-PCR, a technique with greater discriminatory power, it is shown in this study that the $F$ strains derived from contact partners were identical, while $F$ strains from the non-partners studied were genetically different. Although the genetic variation of $F$ strains needs to be studied in more isolates, the APPCR results so far clearly show the sexual transmission from an individual strain between sex partners. The fact that the strains derived from partners were identical, also demonstrates that the AP-PCRs were reproducible and suitable for analysing chlamydial genomic DNA. Whether the genetic differences found in serovar $F$ isolates are related to differences in cell biology or in virulence in chlamydial infections needs to be further investigated. In future studies a more simplified test for individual fingerprinting should be developed, and strain variations in a larger group of serovar $F$ isolates as well as other frequently prevalent serovars (such as D and $\mathrm{E}$ ) need to be investigated. This could be of great value for $C$ trachomatis contact studies.

In conclusion, this study shows that in urogenital $C$ trachomatis infections the majority of heterosexual partners, when identified to be chlamydia positive, are infected with identical serovars. The transmission of a certain serovar might be more dependent on the anatomical site of the actual contact. The fact that the highly prevalent serovar $F$ does possess genetic variation warrants a future contact study of $C$ trachomatis molecular epidemiology based on genomic DNA analysis with AP-PCR.

The work was supported by grant 28-1182 from the Prevention Fund, The Netherlands. The authors thank Dr H Fennema, Dr $G$ van Doornum, J Kint and $H$ van Haastrech for their valuable assistance in conducting this study.

1 Kuo CC, Wang S-P, Holmes KK, Grayston JT. Immunotypes of Chlamydia trachomatis isolates in Seattle, Washington. Infect Immun 1983;41:865-8

2 Wagenvoort JHT, Suchland RJ, Stamm WE. Serovar distribution of urogenital Chlamydia trachomatis strains in the Netherlands. Genitourin Med 1988;64:159-61.

3 Persson K. Epidemiology of serovars of Chlamydia trachomatis. In: Bowie WR, Caldwell HD, Jones RP Mardh PA, Ridgway GL, Schachter J, Stamm WE, and Ward ME, eds. Chlamydia Infections. Cambridge University Press, Cambridge. 1990;559-62.

4 Gaydos CH, Bobo L, Welsh L, Hook III EW, Viscidi R, Quinn TC. Gene typing of Chlamydia trachomatis by polymerase chain reaction and restriction endonuclease digestion. Sex Transm Dis 1992;19:303-8.

5 Rodriguez P, de Barbeyrac B, Persson K, Dutilh B, Bebea C. Evaluation of molecular typing for epidemiology study of Chlamydia trachomatis genital infections. 7 Clin study of Chlamydia trachomat

5a Viscidi RP, Bobo L, Hook III EW, Quinn TC Transmission of Chlamydia trachomatis among sex partners assessed by polymerase chain reaction. $\mathcal{F}$ Infect $D$ is 1993;168:488-92.

6 Wang S-P, Grayston JH. Serotyping of Chlamydia trachomatis by indirect fluorescent-antibody staining of inclusions in cell culture with monoclonal antibodies. Clin Microbiol 1991;29:1295-8.

7 Suchland RJ, Stamm W. Simplified microtiter cell culture method for rapid immunotyping of Chlamydia trachomamethod for rapid immunotyping of

8 Frost EH, Deslandes S, Veilleux S, Bourgaux-Ramoisy D. Typing Chlamydia trachomatis by detection of restriction fragment length polymorphism in the gene encoding the fragment length polymorphism in the gene encoding the
major outer membrane protein. $f$ Infect Dis 1991; major outer

9 Sayada C, Denamur E, Orfila J, Catalan F, Elion J. Rapid genotyping of the Chlamydia trachomatis major oute membrane protein by the polymerase chain reaction. FEMS Microbiol Lett 1991;83:73-8.

10 Frost EH, Deslanders S, Bourgaux-Ramoisy D. Sensitive detection and typing of Chlamydia trachomatis using nested polymerase chain reaction. Genitourin Med 1993;69:290-4.

11 Lan J, Walboomers JMM, Roosendaal R, van Doornum GJj, et al. Direct detection and genotyping of Chlamydia trachomatis in cervical scrapes by using polymerase chain trachomatis in cervical scrapes by using polymerase chain reaction and restriction fragment length

12 Lan J, Ossewaarde JM, Walboomers JMM, Meijer CJLM, van den Brule AJC. Improved PCR sensitivity for direct van den Brule AJC. Improved PCR sensitivity for direct genotyping of Chlamydia trachomatis serovars by using a nested PCR. F Clin Microbiol 1994;32:528-30.

13 Saito J, Takada M. Detection of Chlamydia trachomatis and the serovar determination using PCR and dot-blo hybridization. fapan Clin 1992;50:412-7.

14 Yuan Y, Zhang Y-X, Watkins NG, Caldwell HD 
Nucleotide and deduced amino acid sequencies for the four variable domains of the major outer membrane proteins of the 15 Chlamydia trachomatis serovars. Infect Immun 1989;57:1040-9.

15 Poole E, Lamont I. Chlamydia trachomatis serovar differentiation by direct sequence analysis of the variable segement 4 region of the major outer membrane protein ment 4 region of the major outer

16 Dean D, Schachter J, Dawson CR, Stephens S. Comparison of the major out membrane protein variant sequence regions of $\mathrm{B} / \mathrm{Ba}$ isolates: A molecular epidemiologic approach to Chlamydia trachomatis infections. $\mathcal{F}$ Infect Dis 1992;166:383-92.

17 Wang S-P, Grayton JT. Three new serovars of Chlamydia trachomatis: Da, Ia, and L2a. F Infect Dis 1991;163: 403-5.

18 Dean D, Patton M, Stephens RS. Direct sequence evaluation of the major outer membrane protein gene variant regions of Chlamydia trachomatis subtypes $\mathrm{D}^{\prime}, \mathrm{I}^{\prime}$, and regions of Chlamydia trachomatis subt

19 Lampe MF, Suchland RJ, Stammn WE. Nucleotide sequence of the variable domains within the major outer membrane protein gene from serovariants of Chlamydia trachomatis. Infect Immun 1993;61:213-9.

20 Yang C-L, Maclean I, Brunham R. DNA sequence polymorphism of the Chlamydia trachomatis ompl gene. $f$ Infect Dis 1993;168:1125-30.

21 Lan J, Ossewaarde JM, van Doornum GJ, Walboomers JMM, Meijer CJLM, van den Brule AJC. Serotyping and genotyping of genital Chlamydia trachomatis isolates reveal variants of serovar $\mathrm{Ba}, \mathrm{G}$ and J confirmed by $0 \mathrm{mpl}$ reveal variants of serovar $\mathrm{Ba}, \mathrm{G}$ and $\mathrm{J}$ confirm

22 Sayada C, Denamur E, Xerri B, Orfila J, Elion CJ. A study of Chlamydia trachomatis epidemiology using molecular analysis of the gene encoding the major outer membrane protein. Path Biol 1992;40:583-9.

23 Caetano-Anollés G, Bassam BJ, Gresshoff PM. Primertemplate interactions during DNA amplification fingerprinting with single arbitrary oligonucleotides. Mol Gen printing with single arbita

24 Versalovic J, Koeuth T, Lupski JR. Distribution of repetitive DNA sequences in eubacteria and application to fingerprinting of bacteria genomes. Nucl Acid Res 1991; 19:6823-31

25 Welsh J, MaClelland M.. Fingerprinting genomes using PCR with arbitrary primers. Nucl Acid Res 1990;18: 7213-8.

26 Scieux C, Grimont F, Regnault B, Bianchi A, Kowalski S, Grimont PAD. Molecular typing of Chlamydia trachomatis by random amplification of polymorphic DNA. Res Microbiol 1993;144:395-404.

27 van den Hoek JAR, van Haastrecht HJA, Fennema JSA, Kint JAPCM, van Door GJ, Coutinho RA. Voorkomen en risicofactoren van infectie met Chlamydia trachomatis bij bezoekers van een geslachtsziektenpolikiniek. Ned bij bezoekers van een geslachtsziek
Tijdschr Geneeskd. 1989;133:2392-6.

28 Ossewaarde JM, Manten JW, Hooft HJ, Hekker AC. An enzyme immunoassay to detect specific antibodies of protein and lipipolysaccharide antigens of Chlamydia trachomatis. F Immuno Meth 1989;123:293-8.

29 Lan J, van den Brule AJC, Hemrika DJ, et al. Chlamydia trachomatis and ectopic pregnancy: retrospective analysis of salpingectomy specimens, endometrial biopsies and cervical smears. 7 Clin Pathol 1995;48:815-9.

30 Workowski KA, Stevens CE, Suchland RJ, et al. Clinical manifestation of genital infection due to Chlamydia trachomatis in women: differences related to serovar. Clin Infect Dis 1994;19:756-60. 